Collection: IUFRO 7.01.00 - Ithéus (Brazil, 2013) \& Beijing (China, 2014)

"Forest Response to Climate Change and Air Pollution"

Guest Editors: Paoletti E, Kozovitz A, Feng Z, Bytnerowicz A

\section{Soil chemical and physical status in semideciduous Atlantic Forest fragments affected by atmospheric deposition in central-eastern São Paulo State, Brazil}

\author{
Márcia Inês Martin Silveira Lopes, Andressa Ribeiro Dos Santos, Carla \\ Zuliani Sandrin Camargo, Patricia Bulbovas, Patrícia Giampaoli, Marisa \\ Domingos
}

The expansion of agricultural, urban and industrial areas in the São Paulo State (SE Brazil) led to the fragmentation of the original semideciduous Atlantic Forest into small, patchy forest remnants. Anthropogenic activities produce a variety of pollutants affecting many ecological processes in these remaining forest fragments through soil acidification and fertilization. In this study, we investigated the soil chemical and physical status of six forest remnants (Paulínia, Holambra, Americana, Jaguariúna, Campinas and Cosmópolis) differently affected by industrial, rural and urban pollution in central-eastern São Paulo in order to determine the soil potential to buffer the inputs of pollutants. Soil samples from $0-10,10-20$ and $20-40 \mathrm{~cm}$ depths were collected in the dry and the wet season and the following variables were analyzed: soil texture, $\mathrm{pH}$ in $\mathrm{CaCl}_{2}$ solution, exchangeable cations and exchange capacity, organic carbon, total nitrogen, extractable sulfur, phosphorus and heavy metals. Distinct buffering capacities were observed in industrial and in rural and urban areas, primarily due to the natural characteristics of the soils, such as soil texture, acidification and organic matter. The forest soils affected by atmospheric deposition from the industrial complex (Paulínia and Americana) were more sandy and acidic $(\mathrm{pH}=3.6)$ than those near rural and urban sources $(\mathrm{pH}=4.5)$. The optimal chemical conditions (high contents of organic matter, exchangeable bases, nitrogen, phosphorus and sulfur) were found in the clay soils of forest remnants located in Campinas and Jaguariúna, which were more affected by rural or urban pollution than by industrial emissions. Such clay soils provide the highest buffering capacity against environmental impacts in the study region.

Keywords: Tropical Soils, Atlantic Forest, Urban, Rural and Industrial Pollution, Soil Acidification, Buffering Capacity

\section{Introduction}

The Brazilian Atlantic biome is recognized as one of the hotspots for the conservation of biodiversity (Forzza et al. 2012), though it is severely affected by diverse human interferences, particularly in the State of São Paulo, southeastern Brazil (Domingos et al. 2003). The semideciduous Atlantic Forest is highly fragmented in central-eastern São Paulo because of the expansion of agriculture and urban and industrial growth (Nalon et al 2008). Besides the reduction of forest cover, human activities bring about a variety of pollutants from combustion of fuels, waste disposal, long-term sewage sludge and fertilizer application and other sources, which may be toxic to the plant community and modify the chemical status of soil, depending on its original chemical and physical conditions (Nriagu 1990, Sharpley 1995, Schaaf et al. 2004, Pouyat et al. 2008, Lucas et al. 2011). Soil nutrients are among the main factors that regulate plant growth and play an important role in the sustainable use of soils; however, their excess due to pollution from human sources may damage the soils and affect the soil-plant relationships. Air pollution may also disrupt other nutrient cycling processes in natural ecosystems, such as the decomposition of litter (Cotrufo et al. 1995).

Most anthropogenic pollutants deposited in forest ecosystems accumulate in the soil surface layers (Ruan et al. 2008), where pollutants are typically immobilized for long pe- $\square$ Instituto de Botânica, Caixa Postal 68041, 04045-972 São Paulo, SP (Brazil)

@ Márcia Inês Martin Silveira Lopes (mimlopes@usp.br)

Received: Jan 30, 2014 - Accepted: Dec 13, 2014

Citation: Lopes MIMS, Ribeiro Dos Santos A, Zuliani Sandrin Camargo C, Bulbovas P, Giampaoli P, Domingos M, 2015. Soil chemical and physical status in semideciduous Atlantic Forest fragments affected by atmospheric deposition in central-eastern São Paulo State, Brazil. iForest 8: 798-808 [online 2015-04-22] URL: http://www.sisef.it/iforest/contents/? id=ifor $1258-007$

Communicated by: Giustino Tonon

riods (Hawkins et al. 1995, Verstraeten et al. 2012). However, these accumulations are considered a "chemical time bomb" (Kabala \& Szerszen 2002, Hovmand et al. 2008), because pollutants will eventually be leached into waterways (Miller \& Friedland 1994).

Increased deposition of sulfur and nitrogen compounds $\left(\mathrm{SO}_{2}, \mathrm{NO}_{\mathrm{x}}\right.$ and $\left.\mathrm{NH}_{3}\right)$ in natural communities induces soil acidification (Falkengren-Grerup \& Tyler 1993, Akselsson et al. 2013, Gao et al. 2013). Soil acidification depletes the basic nutrient cations, causes a decrease of $\mathrm{pH}$, lowers the quality of humus, and accelerates the mobilization of aluminum (Boruvka et al. 2005, Miller \& Watmough 2009). The depletion of basic cations from the forest floor alters the mineral nutrition of trees, modifies tree growth patterns (Klumpp et al. 2002, Högberg et al. 2006, Sebesta et al. 2011) and affects the distribution of roots (Joslin \& Wolfe 1992). As a consequence, biodiversity, vegetation productivity and dynamics of the soil carbon pool are affected (Binkley et al. 2000).

Altogether, such negative effects contribute to the forest decline observed in the Atlantic Rain Forest on the coastal mountain range named Serra do Mar (region of Cubatão, São Paulo State, Brazil). This forest is affected by air pollution from an industrial complex that caused destabilization of the land surface, disturbance of soil processes and landslides (Leitão Filho et al. 1993, Mayer et al. 2000a, 2000b). Furthermore, the large metropolitan regions of the São Paulo State (SE Brazil) are responsible for the intense fragmentation of the semideciduous Atlantic Forest. This is observed in the Metropolitan Campinas Region (MCR) located in the central eastern region of the State (Fig. 1), which is composed of 19 municipalities with different types of land use (industrial, agricultural and urban areas). In addition to fo- 


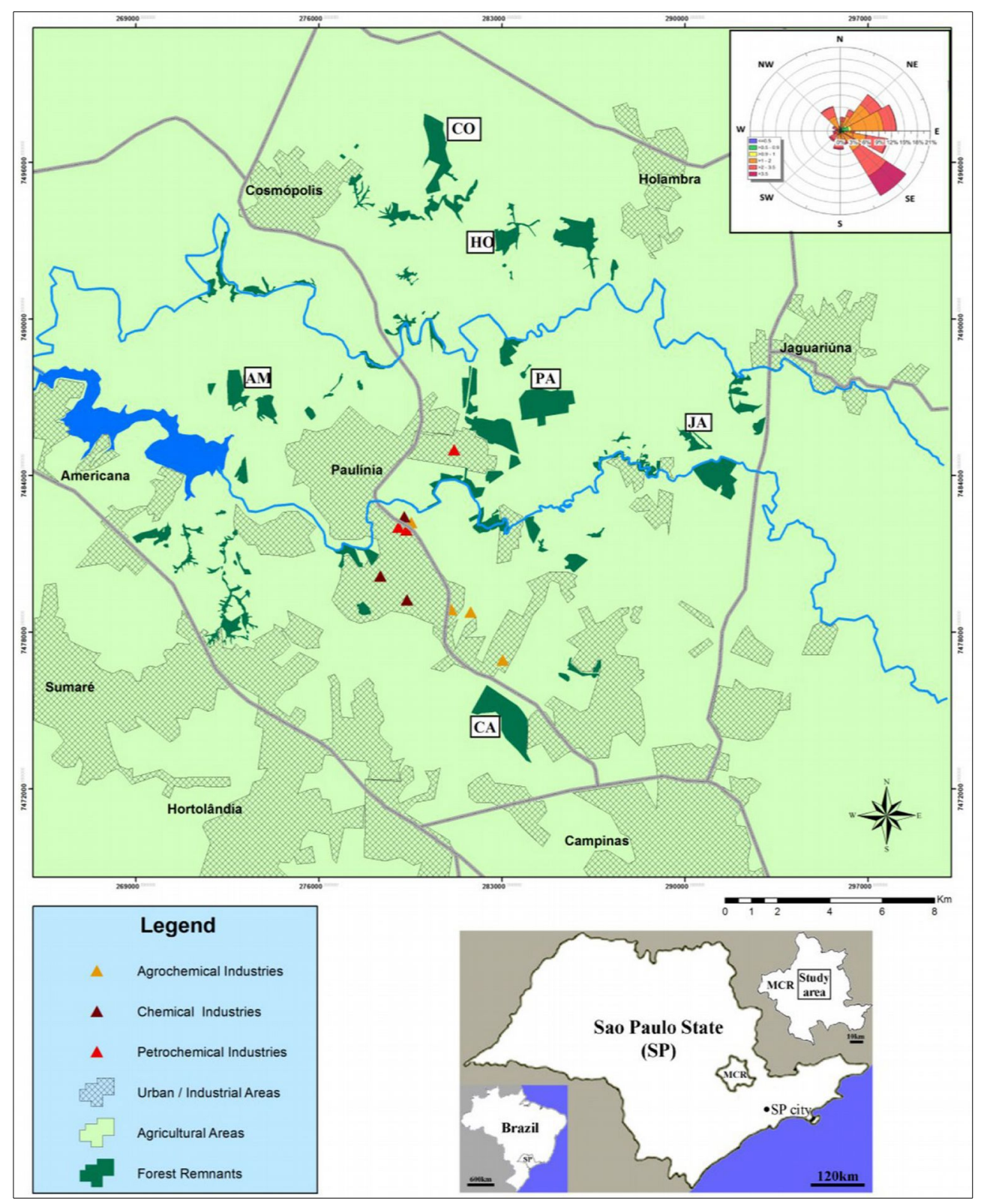

Fig. 1 - Locations of semideciduous Atlantic Forest remnants in the Metropolitan Campinas Region (MCR), Brazil. (PA): Paulínia; (HO): Holambra; (AM): Americana; (JA): Jaguariúna; (CA): Campinas; (CO): Cosmópolis. The wind rose in the upper right corner summarizes the annual wind velocities (shown by distinct colors in $\mathrm{m} \mathrm{s}^{-1}$ ), frequencies (\%) and directions (distributed in the different azimuth degrees).

rest fragmentation, the expansion of agricultural, urban and industrial areas in the MCR has led to increased pollutant emissions, such as sulfur and nitrogen dioxides (CETESB 2012) that acidify the rain (Tresmondi et al. 2005). Unless the natural characteristics of the forest fragments increase the resilience against pollution impacts, the atmospheric contamination and acid rain may endanger the local soil and may affect many of the ecological processes in these remaining forest patches.

Because the soil is usually the most important buffer of forest ecosystems against such impacts, we analyzed the soils of the leftover forest fragments to determine their potential to buffer the pollutant inputs. We investigated the soil chemical and physical status in six forest remnants differently affected by industrial, rural and urban pollution in munici- palities in central-eastern São Paulo. We assumed that wet and dry deposition of air pollutants in the MCR changed the soil chemical status in the semideciduous Atlantic Forest remnants, particularly those located downwind from the industrial area. Additionally, we assumed that soils with high buffering potential against atmospheric deposition in the MCR had the optimal chemical conditions. This study is the first of a series of ecological surveys aimed at assessing the impact of the complex mixture of air pollutants on semideciduous Atlantic Forests in the MCR, and planning the conservation of their high biodiversity.

\section{Material and Methods}

\section{Study area}

Oxisol soils and gentle sloping topography characterize the Metropolitan Campinas Region (MCR - Ker 1997, Prado 1997). The predominant climate in the MCR is classified as B1rB'4a according to the Thornthwaite's typology, or Aw (tropical with dry winter) according to Koeppen's classification (Rolim et al. 2007). The MCR is characterized by a hot and rainy season between October and March and a dry season between April and September. The average temperature ranges from 23.2 to $24.9^{\circ} \mathrm{C}$, and the rainfall is $1142 \mathrm{~mm}$ in the rainy season, while uuring the dry season the average temperature ranges from 18.5 to $23.0^{\circ} \mathrm{C}$, and the rainfall is $283 \mathrm{~mm}$. The predominant wind direction is southeast (see the wind rose included in Fig. 1).

The MCR is the second most important economic center of the São Paulo State and is located $100 \mathrm{~km}$ from the São Paulo metro- 
Tab. 1 - Main characteristics (area, distance from industrial complex, land use in surrounding areas), location (geographical coordinates), soil (litter layer, type, parent material) and vegetation structure (basal area, tree density) of semideciduous Atlantic Forest remnants in the Metropolitan Campinas Region (MCR), Brazil. ( $\left.{ }^{*}\right)$ : Domingos et al. (2015); ( $\left.{ }^{* *}\right)$ : A.R. Santos et al., unpublished data.

\begin{tabular}{|c|c|c|c|c|c|c|}
\hline Characteristics & $\begin{array}{l}\text { Paulínia } \\
\text { (PA) }\end{array}$ & $\begin{array}{l}\text { Holambra } \\
\text { (HO) }\end{array}$ & $\begin{array}{l}\text { Americana } \\
\text { (AM) }\end{array}$ & $\begin{array}{l}\text { Jaguariúna } \\
\text { (JA) }\end{array}$ & $\begin{array}{l}\text { Campinas } \\
\text { (CA) }\end{array}$ & $\begin{array}{l}\text { Cosmópolis } \\
\text { (CO) }\end{array}$ \\
\hline Area (ha) & 180 & 47 & 74 & 6 & 235 & 120 \\
\hline $\begin{array}{l}\text { Distance from industrial } \\
\text { complex }(\mathrm{km})\end{array}$ & 4.5 & 9.3 & 10.0 & 10.5 & 11.2 & 12.1 \\
\hline Geographical coordinates & $\begin{array}{l}22^{\circ} 44^{\prime} 58^{\prime \prime} \mathrm{S} \\
47^{\circ} 05^{\prime} 55^{\prime \prime} \mathrm{W}\end{array}$ & $\begin{array}{l}22^{\circ} 39^{\prime} 33^{\prime \prime} \mathrm{S} \\
47^{\circ} 06^{\prime} 42^{\prime \prime} \mathrm{W}\end{array}$ & $\begin{array}{c}22^{\circ} 42^{\prime} 30^{\prime \prime} \mathrm{S} \\
47^{\circ} 12^{\prime} 40^{\prime \prime} \mathrm{W}\end{array}$ & $\begin{array}{l}22^{\circ} 43^{\prime} 35^{\prime \prime} \mathrm{S} \\
47^{\circ} 01^{\prime} 32^{\prime \prime} \mathrm{W}\end{array}$ & $\begin{array}{l}22^{\circ} 49^{\prime} 22^{\prime \prime} \mathrm{S} \\
47^{\circ} 06^{\prime} 17^{\prime \prime} \mathrm{W}\end{array}$ & $\begin{array}{l}22^{\circ} 37^{\prime} 38^{\prime \prime} \mathrm{S} \\
47^{\circ} 08^{\prime} 02^{\prime \prime} \mathrm{W}\end{array}$ \\
\hline $\begin{array}{l}\text { Land use in surrounding } \\
\text { areas }\end{array}$ & $\begin{array}{l}\text { Industrial/Agricul- } \\
\text { tural (sugarcane) }\end{array}$ & $\begin{array}{c}\text { Agricultural } \\
\text { (citrus sugarcane) }\end{array}$ & $\begin{array}{l}\text { Agricultural } \\
\text { (sugarcane) }\end{array}$ & $\begin{array}{l}\text { Urban/Agricul- } \\
\text { tural (sugarcane) }\end{array}$ & $\begin{array}{l}\text { Urban/Agricul- } \\
\text { tural (sugarcane) }\end{array}$ & $\begin{array}{c}\text { Agricultural } \\
\text { (sugarcane) }\end{array}$ \\
\hline $\begin{array}{l}\text { Basal area } \\
\left(\text { tree } \mathrm{dbh}>10 \mathrm{~cm}, \mathrm{~m}^{2} \mathrm{ha}^{-1}\right)^{*}\end{array}$ & 17.2 & 29.7 & 19.2 & 20.2 & 26.8 & 21.5 \\
\hline Tree density $\left(\text { ind ha }{ }^{-1}\right)^{*}$ & 556 & 588 & 550 & 400 & 528 & 706 \\
\hline Litter layer $\left(\mathrm{Mg} \mathrm{ha}^{-1}\right)^{* *}$ & 9.1 & 10.3 & 9.1 & 11.8 & 10.5 & 8.1 \\
\hline Soil Type & red-yellow oxisol & red-yellow oxisol & red-yellow oxisol & red oxisol & red oxisol & red-yellow oxisol \\
\hline Parent material & $\begin{array}{c}\text { diabase } \\
\text { sandstone }\end{array}$ & Sandstone & $\begin{array}{c}\text { siltstone } \\
\text { rhythmites }\end{array}$ & diabase & diabase & $\begin{array}{c}\text { diabase sandstone } \\
\text { siltstone }\end{array}$ \\
\hline
\end{tabular}

politan region. The largest Brazilian oil refinery is located in Paulínia, which refines $20 \%$ of the crude oil in Brazil. Moreover, the industrial complex includes chemical, pharmaceutical and fertilizer industries (Tresmondi \& Tomaz 2004). The high vehicle traffic associated with industrial and extensive agriculture activities remarkably contributes to increase the atmospheric pollution of the region (Miranda \& Tomaz 2008).

Six semideciduous forest remnants were selected at different distances from the industrial areas of Paulínía, Holambra, Americana, Jaguariúna, Campinas and Cosmópolis municipalities (Fig. 1, Tab. 1). The largest forest remnant was located in Campinas (235 ha), followed by those in Paulínia (180 ha) and Cosmópolis (120 ha). Tree density varied from 400 ind ha ${ }^{-1}$ in Jaguariúna to 706 ind $\mathrm{ha}^{-1}$ in Cosmópolis, and the basal area ranged from $17.2 \mathrm{~m}^{2} \mathrm{ha}^{-1}$ in Paulínia to 29.7 $\mathrm{m}^{2} \mathrm{ha}^{-1}$ in Holambra. The soils were formed from different parent materials, from sandstone to diabase, which resulted in oxisols with medium (red-yellow oxisol) to high fertility (red oxisol). All forest remnants contained considerable litter stocks (8.1-11.8 $\left.\mathrm{Mg} \mathrm{ha}^{-1}\right)$, as typically observed in other tropical forests (Ostertag et al. 2008, Tang et al. 2010). The predominant land use around the forest remnants is agriculture in Holambra and Americana, industry and agriculture in Paulínia, while a mix of urban and agricultural areas is found in Campinas and Jaguariúna (Tab. 1).

\section{Soil sampling and analyses}

Soil sampling procedures were based on protocols for monitoring European forests (Cools \& Des Vos 2011, Ferretti et al. 2010, Filizola et al. 2006), modified according to the forest physiognomy and environmental conditions found in the tropics. Two plots of $140 \times 50 \mathrm{~m}$ were established at each sam- pling site (forest remnant) $100 \mathrm{~m}$ apart from the forest edge, totalling $14000 \mathrm{~m}^{2}$ at each site. Twenty-four soil samples were collected in each plot at $0-10,10-20$ and $20-40 \mathrm{~cm}$ depths in July 2010 (dry season) and January 2011 (wet season). Three composite samples per plot, layer and season $(n=12)$ were analyzed for each forest remnant, which were obtained by randomly mixing eight individual soil samples.

Samples were air-dried, sieved through a 2 $\mathrm{mm}$ sieve and analyzed for texture, soil nutrients and heavy metals, according to EMBRAPA (1997). Soil texture (granulometry) was determined with the Boyoucos hydrometer method. The soil $\mathrm{pH}$ was measured in $0.01 \mathrm{~mol} \mathrm{~L}^{-1} \mathrm{CaCl}_{2}$ solution (soil/ $\mathrm{CaCl}_{2}$ ratio 1:2.5). Available phosphorus (P) and the exchangeable potassium $(\mathrm{K})$, calcium $(\mathrm{Ca})$ and magnesium $(\mathrm{Mg})$ from soils were simultaneously extracted using a ion-exchange resins, following the method proposed by Raij et al. (1986). The extraction procedure included the disaggregation of soil by shaking in water, the transfer of elements from the soil to a sodium bicarbonate treated mixture of anion and cation exchange resins, and the separation of the resin from the soil by sieving and extraction of elements from the resin. Phosphorus was determined spectrophotometrically with the molybdenum blue complex, $\mathrm{K}$ by the flame emission spectrometry, and $\mathrm{Ca}$ and $\mathrm{Mg}$ with the atomic absorption spectrometry. $\mathrm{Al}$ was extracted with a $\mathrm{KCl}$ solution $\left(1 \mathrm{~mol} \mathrm{~L}^{-1}\right)$ and determined by titration with $0.025 \mathrm{~mol} \mathrm{~L}^{-1} \mathrm{NaOH}$. The organic carbon (Corg) was determined by colorimetry, after organic matter oxidation with $\mathrm{Na}_{2} \mathrm{Cr}_{2} \mathrm{O}_{7} 2 \mathrm{H}_{2} \mathrm{O}$ and $\mathrm{H}_{2} \mathrm{SO}_{4}$. Total nitrogen (Ntot) was determined by the Kjeldahl distillation method, after $\mathrm{H}_{2} \mathrm{SO}_{4}$ digestion. Extractable sulfur $(\mathrm{S})$ was determined by the turbidimetric method in soil extracts prepared with $\mathrm{Ca}\left(\mathrm{HPO}_{4}\right)_{2}$. Extractable heavy metals $(\mathrm{Cu}, \mathrm{Fe}, \mathrm{Mn}$ and $\mathrm{Zn})$ in soil extracts prepared with DTPA-TEA were determined with atomic absorption spectrometry. The cation exchange capacity $(\mathrm{CEC}=\mathrm{Ca}+\mathrm{Mg}+$ $\mathrm{K}+\mathrm{Al}+\mathrm{H})$, aluminum saturation $(\mathrm{m} \%=[\mathrm{Al} /$ $\mathrm{Ca}+\mathrm{Mg}+\mathrm{K}+\mathrm{Al}] \cdot 100)$, base saturation $(\mathrm{V} \%=$ $[(\mathrm{Ca}+\mathrm{Mg}+\mathrm{K}) / \mathrm{CEC}] \cdot 100)$ and $\mathrm{C} / \mathrm{N}$ ratio were calculated.

\section{Statistical analyses}

Differences in physical and chemical soil properties among forest remnants (sampling sites) were tested by non-parametric ANOVA (Kruskal-Wallis test $-\alpha=0.05$ ), followed by multiple-comparison tests (Dunn's method). Pairwise Spearman's correlation coefficients among soil characteristics were also calculated for testing variable associations. All the above statistical analyses were performed using the software package SigmaPlot ${ }^{\circledR}$ ver. 11.0 (Systat Software Inc., San José, CA, USA).

Principal component analyses (PCA) using the software package PC-ORD ${ }^{\circledR} 6.0(\mathrm{MjM}$ Software Design, Gleneden Beach, OR, USA) and cluster analysis using the SPSS ${ }^{\circledR}$ 7.0 software (IBM, NY, USA) were performed to group similar forest remnants based on soil variables after $\log _{10}$ transformation $\left(\mathrm{pH}-\mathrm{CaCl}_{2}\right.$, carbon, nitrogen, $\mathrm{C} / \mathrm{N}$ ratio, phosphorus, sulfur, cation exchange capacity, aluminum saturation, base saturation, copper, iron, manganese, zinc, sand and clay). Cluster analysis was perfomed using the Ward's algorithm, and the distances between the fifteen variables were calculated by Pearson's correlation.

\section{Results}

Soil texture (granulometry) at all depths was sandy-clay in Americana, sandy-clayloam in Paulínia, Holambra and Cosmópolis and clay in Jaguariúna and Campinas (Tab. 2). Significant negative correlations ( $p<$ 
Tab. 2 - Soil texture at 0-10 cm, 10-20 cm and 20-40 cm depths of semideciduous Atlantic Forest remnants in the Metropolitan Campinas Region (MCR), Brazil (mean \pm standard error, $\mathrm{n}=12$ ).

\begin{tabular}{lrcccc}
\hline Sampling site & $\begin{array}{c}\text { Depth } \\
(\mathbf{c m})\end{array}$ & $\begin{array}{c}\text { Sand } \\
\left(\mathbf{g ~ k g}^{-1}\right)\end{array}$ & $\begin{array}{c}\text { Silt } \\
\left(\mathbf{g ~ k g}^{-1}\right)\end{array}$ & $\begin{array}{c}\text { Clay } \\
\left(\mathbf{g ~ k g} \mathbf{~ g}^{-1}\right)\end{array}$ & Texture \\
\hline Paulínia (PA) & $0-10$ & $698 \pm 37$ & $55 \pm 6$ & $247 \pm 33$ & Sandy-clay-loam \\
& $10-20$ & $684 \pm 33$ & $49 \pm 6$ & $267 \pm 29$ & Sandy-clay-loam \\
& $20-40$ & $666 \pm 36$ & $46 \pm 4$ & $288 \pm 33$ & Sandy-clay-loam \\
\hline Holambra (HO) & $0-10$ & $702 \pm 20$ & $81 \pm 15$ & $217 \pm 15$ & Sandy-clay-loam \\
& $10-20$ & $704 \pm 19$ & $79 \pm 8$ & $217 \pm 16$ & Sandy-clay-loam \\
& $20-40$ & $700 \pm 19$ & $74 \pm 9$ & $226 \pm 16$ & Sandy-clay-loam \\
\hline Americana (AM) & $0-10$ & $559 \pm 12$ & $75 \pm 13$ & $366 \pm 18$ & Sandy-clay \\
& $10-20$ & $546 \pm 13$ & $78 \pm 15$ & $376 \pm 16$ & Sandy-clay \\
& $20-40$ & $521 \pm 12$ & $86 \pm 10$ & $393 \pm 16$ & Sandy-clay \\
\hline Jaguariúna (JA) & $0-10$ & $346 \pm 6$ & $90 \pm 2$ & $564 \pm 4$ & Clay \\
& $10-20$ & $321 \pm 6$ & $77 \pm 7$ & $602 \pm 1$ & Clay \\
& $20-40$ & $301 \pm 6$ & $85 \pm 2$ & $614 \pm 4$ & Clay \\
\hline Campinas (CA) & $0-10$ & $372 \pm 29$ & $168 \pm 4$ & $460 \pm 29$ & Clay \\
& $10-20$ & $340 \pm 26$ & $163 \pm 5$ & $497 \pm 29$ & Clay \\
& $20-40$ & $353 \pm 28$ & $171 \pm 6$ & $476 \pm 31$ & Clay \\
\hline Cosmópolis (CO) & $0-10$ & $731 \pm 17$ & $55 \pm 6$ & $214 \pm 13$ & Sandy-clay-loam \\
& $10-20$ & $714 \pm 19$ & $52 \pm 6$ & $234 \pm 13$ & Sandy-clay-loam \\
& $20-40$ & $693 \pm 18$ & $56 \pm 7$ & $251 \pm 14$ & Sandy-clay-loam \\
\hline
\end{tabular}

0.001) were found between the sand content and Corg, Ntot, $\mathrm{S}$ and $\mathrm{Cu}$ concentrations in soils. Conversely, significant positive correlations were identified between the above elements and the clay content (Tab. 3).

The variation with depth of soil chemical parameters are presented in Fig. 2 to 5 . All elements decreased in concentration from the surface to the deeper soil layers, with the exceptions of $\mathrm{S}$ and $\mathrm{Al}$.

The largest amounts of Corg, Ntot, and extractable $\mathrm{P}$ and $\mathrm{S}$ were found in soils from Jaguariúna and Campinas $(\mathrm{p}<0.05)$, whereas the lowest levels were found in Holambra and Cosmópolis (Fig. 2). The Corg contents varied from medium $\left(<15 \mathrm{~g} \mathrm{dm}^{-3}\right)$ to high $\left(20\right.$ to $31 \mathrm{~g} \mathrm{dm}^{-3}$ ) and were directly related to the high levels of organic matter. The Corg in soils was correlated positively with Ntot, $\mathrm{CEC}, \mathrm{P}$ and $\mathrm{Cu}$. The Ntot content was correlated with the same parameters, as well as with $\mathrm{S}$ content (Tab. 3).

The extractable $\mathrm{P}$ and $\mathrm{S}$ levels were similar in the soils of sampling sites in Paulínia, Holambra, Americana and Cosmópolis and were significantly higher in Jaguariúna and Campinas ( $p<0.05$ - Fig. 2). The P content values were significantly and positively correlated with $\mathrm{CEC}$ and $\mathrm{Cu}$ concentrations (Tab. 3).

The $\mathrm{C} / \mathrm{N}$ ratio $(<11 / 1)$ was low and similar in all sampling sites. Primarily in Jaguariúna and Campinas soils, such ratio indicated an optimal decomposition of the soil organic matter (Fig. 2).

The soils were extremely acidic in all the forest remnants analyzed ( $\mathrm{pH}<4.5$ - Fig. 3). However, $\mathrm{pH}$ values of soil samples from Americana and Paulínia (3.6-3.9) were lower than those from Jaguariúna and Campinas (4.0-4.5).

Soil samples from Jaguariúna and Campinas sites had low Al concentrations (0.5-0.6 cmol $\mathrm{dm}^{-3}$ ), high base saturation (28-29\%), and high contents of exchangeable $\mathrm{Ca}$ (2.6$\left.2.9 \mathrm{cmol} \mathrm{dm}^{-3}\right)$ and $\mathrm{Mg}\left(0.9-1.5 \mathrm{cmol} \mathrm{dm}^{-3}\right)$, available P $\left(0.15-0.21 \mathrm{cmol} \mathrm{dm}^{-3}\right)$, Corg (27$\left.31 \mathrm{~g} \mathrm{dm}^{-3}\right)$ and Ntot $\left(2.8-3.2 \mathrm{~g} \mathrm{dm}^{-3}\right)$ in the surface layer (Fig. 3, Fig. 4). By contrast, high $\mathrm{Al}$ content and low basic cations $(\mathrm{Ca}$, $\mathrm{Mg}$ and $\mathrm{K}$ ) were found in the Americana soil (Fig. 3, Fig. 4). Correlation analysis revealed significant negative associations between $\mathrm{CEC}$ and $\mathrm{V} \%, \mathrm{~V} \%$ and $\mathrm{m} \%$ or $\mathrm{Fe}$, and $\mathrm{m} \%$ and $\mathrm{Mn}$ or $\mathrm{Zn}$. Positive associations were found between CEC and $\mathrm{m} \%, \mathrm{Fe}$ or $\mathrm{Mn}$, and $\mathrm{V} \%$ and $\mathrm{Mn}$ or Zn (Tab. 3).

The studied forest sites had different concentrations of available heavy metals (Fig. 5). The levels of $\mathrm{Cu}\left(5.0 \mathrm{mg} \mathrm{dm}^{-3}\right)$ and $\mathrm{Zn}$ $\left(2.4 \mathrm{mg} \mathrm{dm}^{-3}\right)$ were significantly higher in the Campinas soil. The levels of $\mathrm{Fe}$ in the Americana (228 $\left.\mathrm{mg} \mathrm{dm}^{-3}\right)$ and Paulínia (208 $\mathrm{mg} \mathrm{dm}^{-3}$ ) soils were significantly higher. Higher levels of Mn were detected in the soil from the Holambra forest $\left(64.4 \mathrm{mg} \mathrm{dm}^{-3}\right)$. The available levels of $\mathrm{Zn}$ and $\mathrm{Mn}$ showed a significant positive correlation with each other. Levels of Mn were negatively correlated with $\mathrm{Fe}$ contents (Tab. 3).

Tab. 4 summarizes the results of the correlation analysis between $\mathrm{pH}$ values and soil characteristics for each forest fragment studied. The soil $\mathrm{pH}$ in the Paulínia forest was negatively correlated with Ntot, $\mathrm{Al}, \mathrm{CEC}, \mathrm{m}$ $\%, \mathrm{Cu}, \mathrm{Fe}$ and sand and was positively correlated with Mn, silt and clay. In the Holambra site, the $\mathrm{pH}$ was negatively correlated with $\mathrm{Al}$ and $\mathrm{m} \%$ and was positively correlated with $\mathrm{K}, \mathrm{Ca}, \mathrm{Mg}, \mathrm{V} \%, \mathrm{Mn}$ and $\mathrm{Zn}$. The $\mathrm{pH}$

Tab. 3 - Spearman's correlation coefficients among edaphic variables in the 0-10 cm soil layer in semideciduous Atlantic Forest remnants in the Metropolitan Campinas Region (MCR), Brazil. (CEC): Cation exchange capacity $=\mathrm{Ca}+\mathrm{Mg}+\mathrm{K}+\mathrm{Al}+\mathrm{H}$; $(\mathrm{V} \%)$ : Base saturation $=$ $[(\mathrm{Ca}+\mathrm{Mg}+\mathrm{K}) / \mathrm{CEC}] \cdot 100 ;(\mathrm{m} \%)$ : Aluminum saturation $=(\mathrm{Al} / \mathrm{Ca}+\mathrm{Mg}+\mathrm{K}+\mathrm{Al}) \cdot 100 .\left({ }^{*}\right): \mathrm{p}<0.05 ;(* *): \mathrm{p}<0.01 ;(* * *): \mathrm{p}<0.001$.

\begin{tabular}{|c|c|c|c|c|c|c|c|c|c|c|c|c|c|}
\hline Variable & Corg & Ntot & $\mathbf{P}$ & $\mathbf{S}$ & CEC & $V \%$ & $\mathrm{~m} \%$ & $\mathbf{C u}$ & $\mathrm{Fe}$ & Mn & $\mathrm{Zn}$ & Sand & Clay \\
\hline Corg & 1.00 & - & - & - & - & - & - & - & - & - & - & - & - \\
\hline Ntot & $0.86^{* * *}$ & 1.00 & - & - & - & - & - & - & - & - & - & - & - \\
\hline $\mathbf{P}$ & $0.67 * * *$ & $0.65^{* * *}$ & 1.00 & - & - & - & - & - & - & - & - & - & - \\
\hline $\mathbf{S}$ & 0.34 & $0.56^{* * *}$ & 0.43 & 1.00 & - & - & - & - & - & - & - & - & - \\
\hline CEC & $0.74 * * *$ & $0.65 * * *$ & $0.67 * *$ & 0.35 & 1.00 & - & - & - & - & - & - & - & - \\
\hline$V \%$ & -0.04 & 0.04 & 0.30 & 0.07 & $-0.56^{* * *}$ & 1.000 & - & - & - & - & - & - & - \\
\hline $\mathbf{m} \%$ & -0.00 & -0.05 & -0.29 & -0.01 & $0.50 * * *$ & $-0.96 * * *$ & 1.00 & - & - & - & - & - & - \\
\hline $\mathbf{C u}$ & $0.71 * * *$ & $0.69 * * *$ & $0.65^{* * *}$ & 0.33 & 0.43 & 0.20 & -0.26 & 1.00 & - & - & - & - & - \\
\hline $\mathbf{F e}$ & 0.29 & 0.18 & -0.06 & -0.17 & $0.65^{* * *}$ & $-0.79 * * *$ & $0.77 * * *$ & 0.02 & 1.00 & - & - & - & - \\
\hline Mn & -0.25 & -0.27 & 0.08 & -0.16 & $0.65^{* * *}$ & $0.81 * * *$ & $-0.85 * * *$ & 0.10 & $-0.77 * * *$ & 1.00 & - & - & - \\
\hline $\mathbf{Z n}$ & 0.31 & 0.33 & 0.47 & 0.16 & -0.18 & $0.75^{* * *}$ & $-0.75 * * *$ & 0.48 & -0.48 & $0.61 * * *$ & 1.00 & - & - \\
\hline Sand & $-0.55^{* * *}$ & $-0.64 * * *$ & 0.47 & $-0.62 * * *$ & -0.38 & 0.14 & 0.13 & $-0.67 * * *$ & 0.06 & 0.07 & -0.37 & 1.00 & - \\
\hline Clay & $0.53 * * *$ & $0.60 * * *$ & 0.44 & $0.60 * * *$ & 0.41 & 0.06 & -0.05 & $0.58 * * *$ & 0.03 & 0.43 & $-0.95 * * *$ & 0.48 & 1.00 \\
\hline
\end{tabular}


Fig. 2 - Soil organic carbon (A), total nitrogen (B), extractable phosphorus (C) and sulfur (D), and $\mathrm{C} / \mathrm{N}$ ratio (E) at $0-10 \mathrm{~cm}, 10-20 \mathrm{~cm}$ and $20-40 \mathrm{~cm}$ depths of semideciduous Atlantic Forest remnants in the Metropolitan Campinas Region (MCR), Brazil (mean \pm standard error, $n=12)$.
(A)

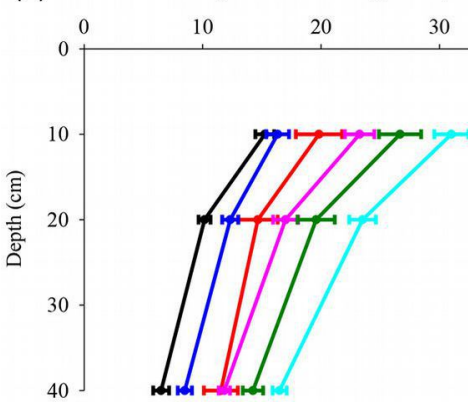

(C)

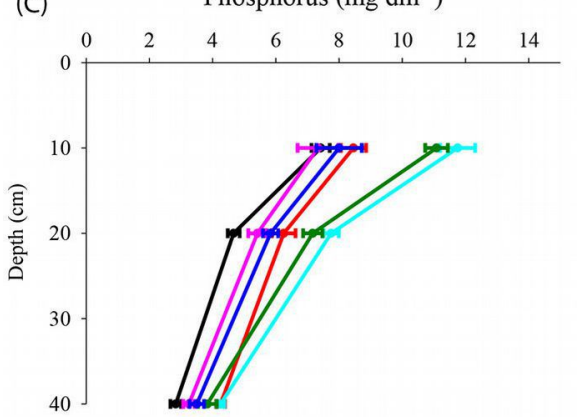

(E)

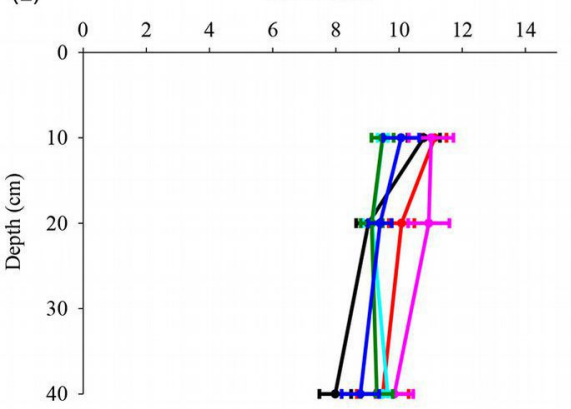

(A)

Fig. 3 - Soil $\mathrm{pH}_{\mathrm{CaCl} 2}(\mathrm{~A})$, cation exchange capacity $\left(\mathrm{CEC}_{\mathrm{pH} 7}-\mathrm{B}\right)$, aluminum saturation (m $\%-\mathrm{C})$ and base saturation $(\mathrm{V} \%-\mathrm{D})$ at $0-10$ $\mathrm{cm}, 10-20 \mathrm{~cm}$ and $20-40 \mathrm{~cm}$ depths of semideciduous Atlantic Forest remnants in the Metropolitan Campinas Region (MCR), Brazil (mean \pm standard error, $\mathrm{n}=12$ ).

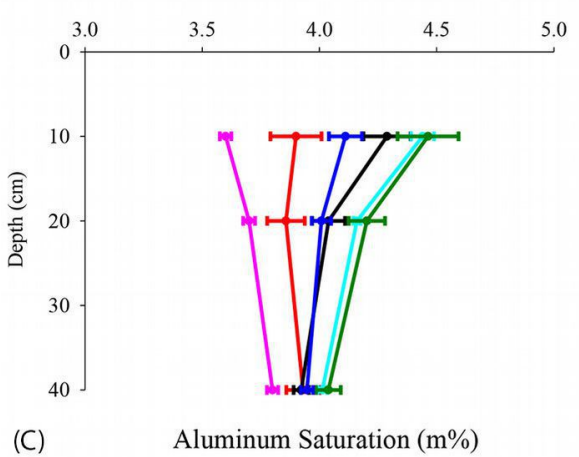

$\begin{array}{llllll}0 & 20 & 40 & 60 & 80 & 100\end{array}$

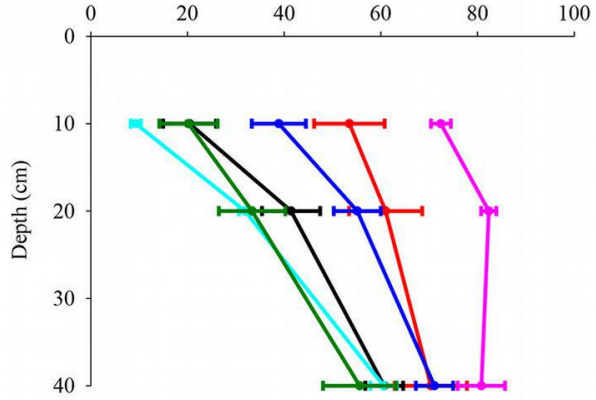

Paulinia Holambra Americana
(B) Total Nitrogen $\left(\mathrm{g} \mathrm{dm}^{-3}\right)$

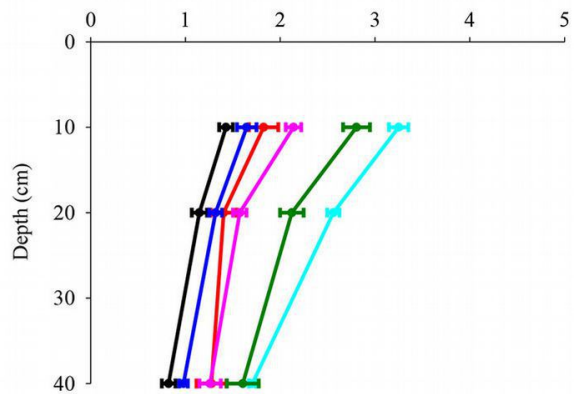

(D)

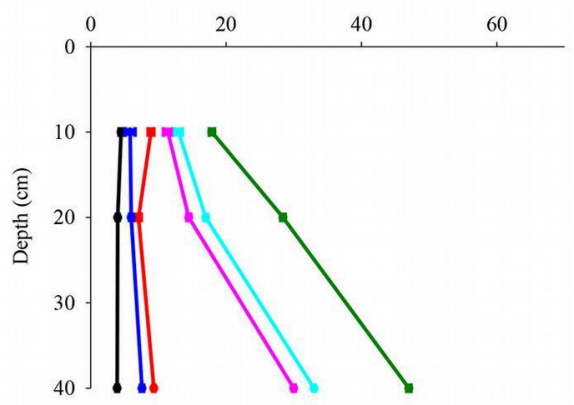

(B) $\quad \mathrm{CEC}_{\mathrm{pH} 7}\left(\mathrm{cmol} \mathrm{dm}^{-3}\right)$

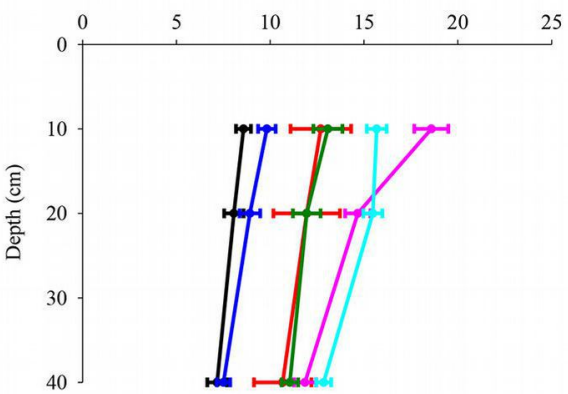

(D) Base Saturation (V\%)

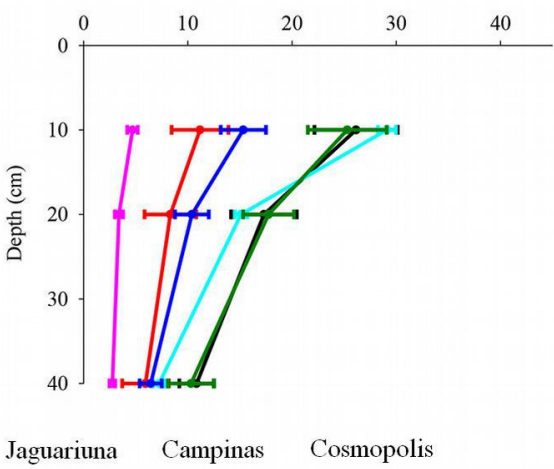




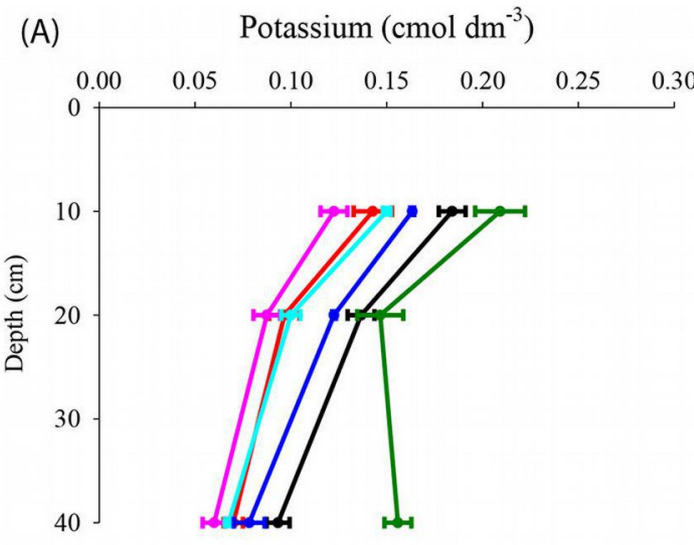

(C)

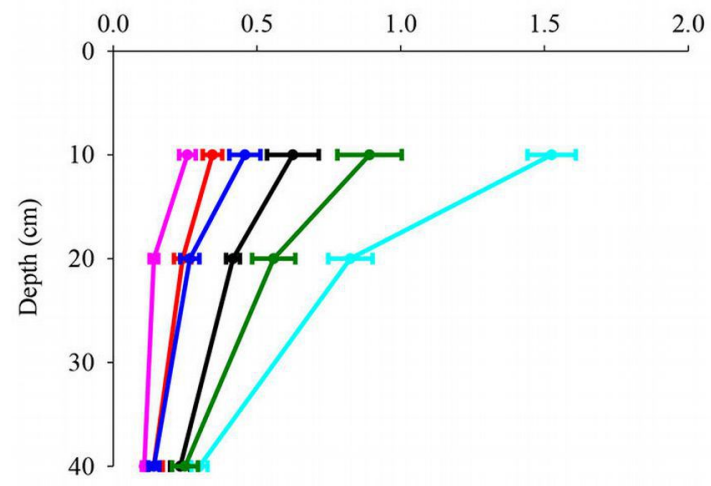

(B)

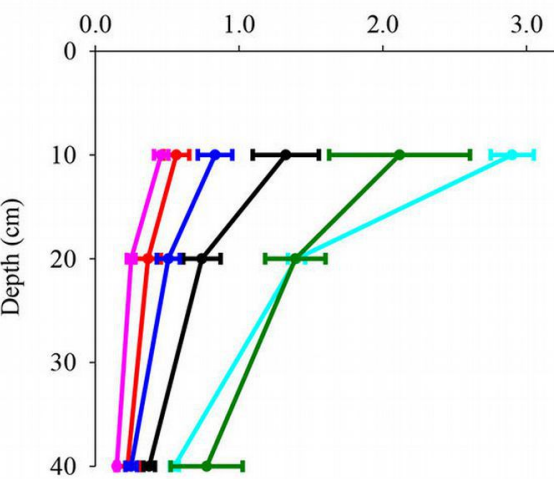

(D)

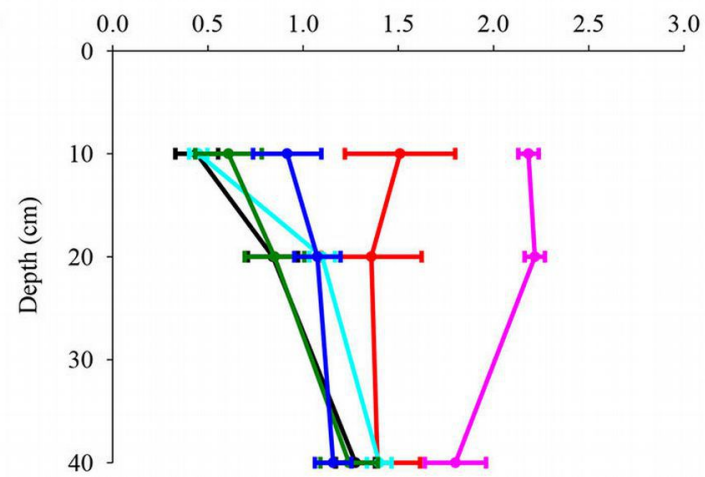

Jaguariuna Campinas Cosmopolis

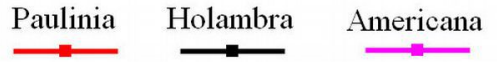

(A)

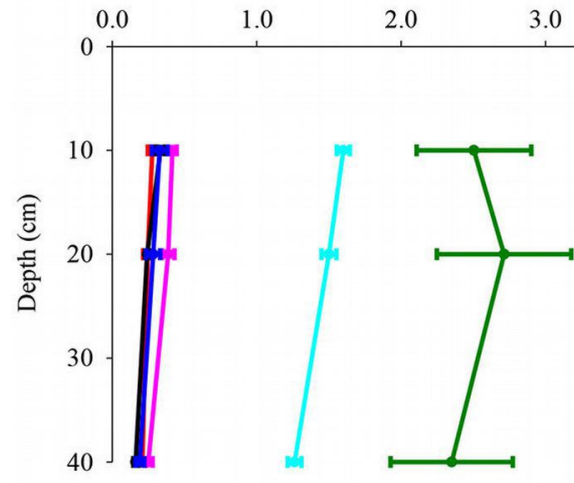

(C)

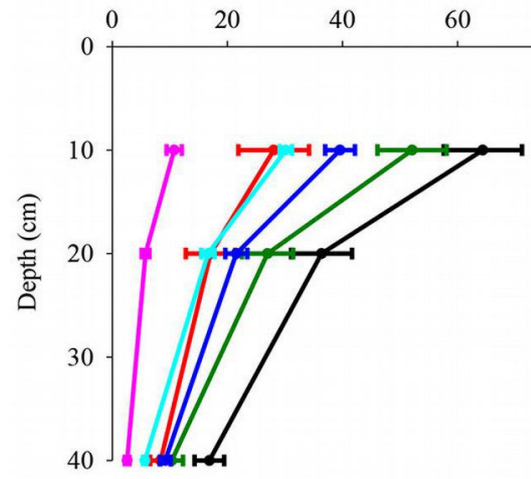

Paulinia Holambra Americana
(B)

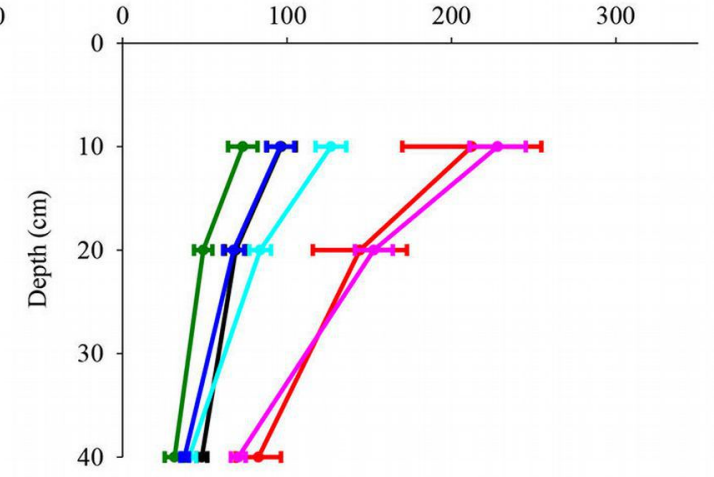

(D)

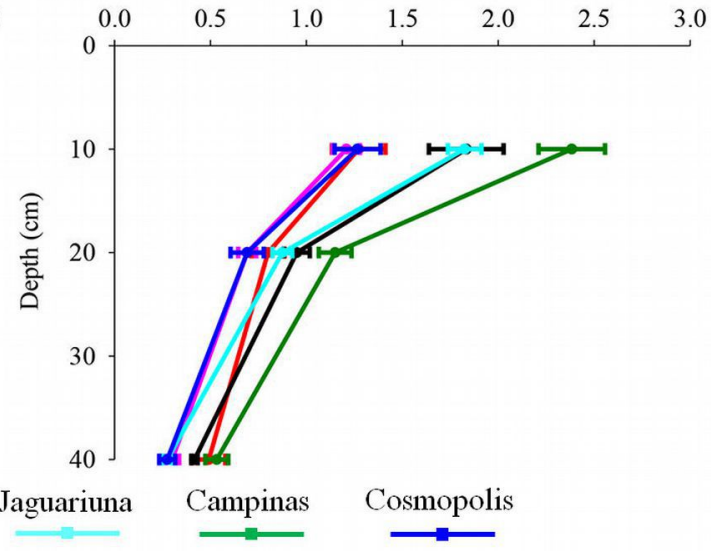

Fig. 4 - Soil exchangeable potassium (A), calcium (B), magnesium (C) and aluminum (D) at $0-10 \mathrm{~cm}$, $10-20 \mathrm{~cm}$ and $20-40 \mathrm{~cm}$ depths of semideciduous Atlantic Forest remnants in the Metropolitan Campinas Region (MCR), Brazil (mean \pm standard error, $\mathrm{n}=$ 12).
Fig. 5 - Soil extractable copper (A), iron (B), manganese (C) and zinc (D) at $0-10 \mathrm{~cm}, 10-20 \mathrm{~cm}$ and 20 $40 \mathrm{~cm}$ depths of semideciduous Atlantic Forest remnants in the Metropolitan Campinas Region (MCR), Brazil (mean \pm standard error, $\mathrm{n}=12$ ). 
Tab. 4 - Spearman's correlation coefficients between $\mathrm{pH}$ and physical and chemical parameters in the $0-40 \mathrm{~cm}$ soil layer in semideciduous Atlantic Forest remnants in the Metropolitan Campinas Region (MCR), Brazil. (PA): Paulína; (HO): Holambra; (AM): Americana; (JA): Jaguariúna; (CA): Campinas; (CO): Cosmópolis; (CEC): cation exchange capacity $=\mathrm{Ca}+\mathrm{Mg}+\mathrm{K}+\mathrm{Al}+\mathrm{H}$; $(\mathrm{V} \%)$ : base saturation = $[(\mathrm{Ca}+\mathrm{Mg}+\mathrm{K}) / \mathrm{CEC}] \cdot 100 ;(\mathrm{m} \%)$ : Aluminum saturation $=(\mathrm{Al} / \mathrm{Ca}+\mathrm{Mg}+\mathrm{K}+\mathrm{Al}) \cdot 100 .(*): \mathrm{p}<0.05 ;(* *): \mathrm{p}<0.01 ;(* * *): \mathrm{p}<0.001$

\begin{tabular}{|c|c|c|c|c|c|c|}
\hline Parameters & $\mathbf{P A}$ & HO & $\mathbf{A M}$ & $\mathbf{J A}$ & CA & $\mathrm{CO}$ \\
\hline Corg & $-0.73 * * *$ & 0.37 & $-0.76^{* * *}$ & $0.88^{* * *}$ & $0.81 * * *$ & 0.28 \\
\hline Ntot & $-0.69 * * *$ & 0.21 & -0.43 & $0.85 * * *$ & $0.76 * * *$ & 0.39 \\
\hline $\mathrm{C} / \mathrm{N}$ & -0.45 & 0.41 & $-0.57 * * *$ & 0.04 & 0.18 & -0.07 \\
\hline $\mathrm{P}$ & -0.46 & 0.49 & $-0.56^{* * *}$ & $0.89 * * *$ & $0.65 * * *$ & 0.33 \\
\hline $\mathrm{S}$ & -0.27 & 0.36 & $0.73 * * *$ & $-0.76^{* *}$ & 0.12 & 0.06 \\
\hline $\mathrm{K}$ & -0.01 & $0.56^{* * *}$ & $-0.58 * * *$ & $0.92 * * *$ & $0.60 * * *$ & $0.52 * *$ \\
\hline $\mathrm{Ca}$ & 0.45 & $0.87 * * *$ & -0.46 & $0.85^{* * *}$ & $0.74 * * *$ & $0.56^{* * *}$ \\
\hline $\mathrm{Mg}$ & 0.40 & $0.84 * * *$ & $-0.51 * *$ & $0.95 * * *$ & $0.87 * * *$ & $0.53 * *$ \\
\hline $\mathrm{Al}$ & $-0.79 * * *$ & $-0.86 * * *$ & -0.20 & $-0.94 * * *$ & $-0.94 * * *$ & $-0.69 * * *$ \\
\hline $\mathrm{CEC}$ & $-0.88 * * *$ & -0.25 & $-0.84 * * *$ & 0.42 & 0.35 & -0.12 \\
\hline V\% & $0.73 * * *$ & $0.92 * * *$ & -0.12 & $0.89 * * *$ & $0.84 * * *$ & $0.60 * * *$ \\
\hline $\mathrm{m} \%$ & $-0.63 * * *$ & $-0.88 * * *$ & 0.36 & $-0.95 * * *$ & $-0.91 * * *$ & $-0.63 * * *$ \\
\hline $\mathrm{Cu}$ & $-0.50 * * *$ & 0.15 & $-0.76 * * *$ & $0.80 * * *$ & $0.70 * * *$ & 0.09 \\
\hline $\mathrm{Fe}$ & $-0.80 * * *$ & 0.11 & $-0.81 * * *$ & $0.79 * * *$ & -0.23 & 0.03 \\
\hline $\mathrm{Mn}$ & $0.52 * *$ & $0.77 * * *$ & $-0.61 * * *$ & $0.94 * * *$ & $0.80 * * *$ & $0.51 * *$ \\
\hline $\mathrm{Zn}$ & 0.11 & $0.65 * * *$ & $-0.70 * * *$ & $0.85 * * *$ & $0.66^{* * *}$ & 0.39 \\
\hline Sand & $-0.69 * *$ & 0.42 & -0.19 & 0.56 & 0.27 & 0.11 \\
\hline Silt & $0.66^{* *}$ & -0.31 & 0.18 & 0.33 & 0.06 & 0.06 \\
\hline Clay & $0.72 * * *$ & -0.33 & 0.13 & $-0.69 *$ & -0.25 & -0.13 \\
\hline
\end{tabular}

values found in the forest soil from Americana were negatively associated with Corg, Ntot, $\mathrm{C} / \mathrm{N}$ ratio, $\mathrm{P}, \mathrm{K}, \mathrm{CEC}, \mathrm{Cu}, \mathrm{Fe}, \mathrm{Mn}, \mathrm{Zn}$ and sand and were positively associated only with S content. In soil samples from Jaguariúna and Campinas, positive relationships were found between $\mathrm{pH}$ and Corg, Ntot, $\mathrm{P}$, $\mathrm{K}, \mathrm{Ca}, \mathrm{Mg}, \mathrm{V} \%, \mathrm{Cu}, \mathrm{Mn}$ and $\mathrm{Zn}$, and negative relationships were observed between $\mathrm{pH}$ and $\mathrm{S}, \mathrm{Al}, \mathrm{m} \%$ and clay. In soils from the Cosmópolis site, $\mathrm{K}, \mathrm{Ca}, \mathrm{Mg}, \mathrm{V} \%$ and $\mathrm{Mn}$ values were positively correlated with soil $\mathrm{pH}$, whereas and $\mathrm{Al}$ and $\mathrm{m} \%$ were negatively correlated with soil $\mathrm{pH}$.

Fig. 6 and Fig. 7 show the differences in the soil physical and chemical parameters of the forest sites analyzed. The first two principal components accounted for $72 \%$ of the overall variation in the dataset (Fig. 6). The variables clay, $\mathrm{CEC}$, Corg, Ntot, $\mathrm{S}$, and $\mathrm{Cu}$ from Jaguariúna and Campinas were grouped on the positive side of the first PC axis. The second PCA group was made up by $\mathrm{pH}$, $\mathrm{V} \%, \mathrm{P}, \mathrm{Zn}$ and $\mathrm{Mn}$ (negative side of $\mathrm{PC}$ axis 2 - Fig. 6) for all sites in the $0-10 \mathrm{~cm}$ layer, except Americana. For deeper soil layers, the sand fractions from Cosmópolis and Holambra were separated on the negative side of $\mathrm{PC}$ axis 1 and 2 . The variable $\mathrm{m} \%$ was isolated on the positive side of PC axis 2 only for the Americana forest.

The cluster analysis distinguished three groups at a 0.06 linkage distance (Fig. 7). The soil from the Americana forest site was included in the first group, whereas the soils of the Cosmópolis, Paulínia and Holambra forest remnants were included in the second group. Finally, the third group was formed by the soils from Jaguariúna and Campinas.

Fig. 6 - Principal component analysis (PCA) of soil characteristics from 0$10 \mathrm{~cm}$ (10), 10-20 $\mathrm{cm}(20)$ and 20-40 $\mathrm{cm}$ (40) depths of semideciduous Atlantic Forest remnants in the Metropolitan Campinas Region (MCR), Brazil. (PA): Paulínia; (HO): Holambra; (AM): Americana; (JA): Jaguariúna; (CA): Campinas; $(\mathrm{CO})$ : Cosmópolis; (CEC): cation exchange capacity; (V\%): base saturation; $(\mathrm{m} \%)$ : aluminum saturation.

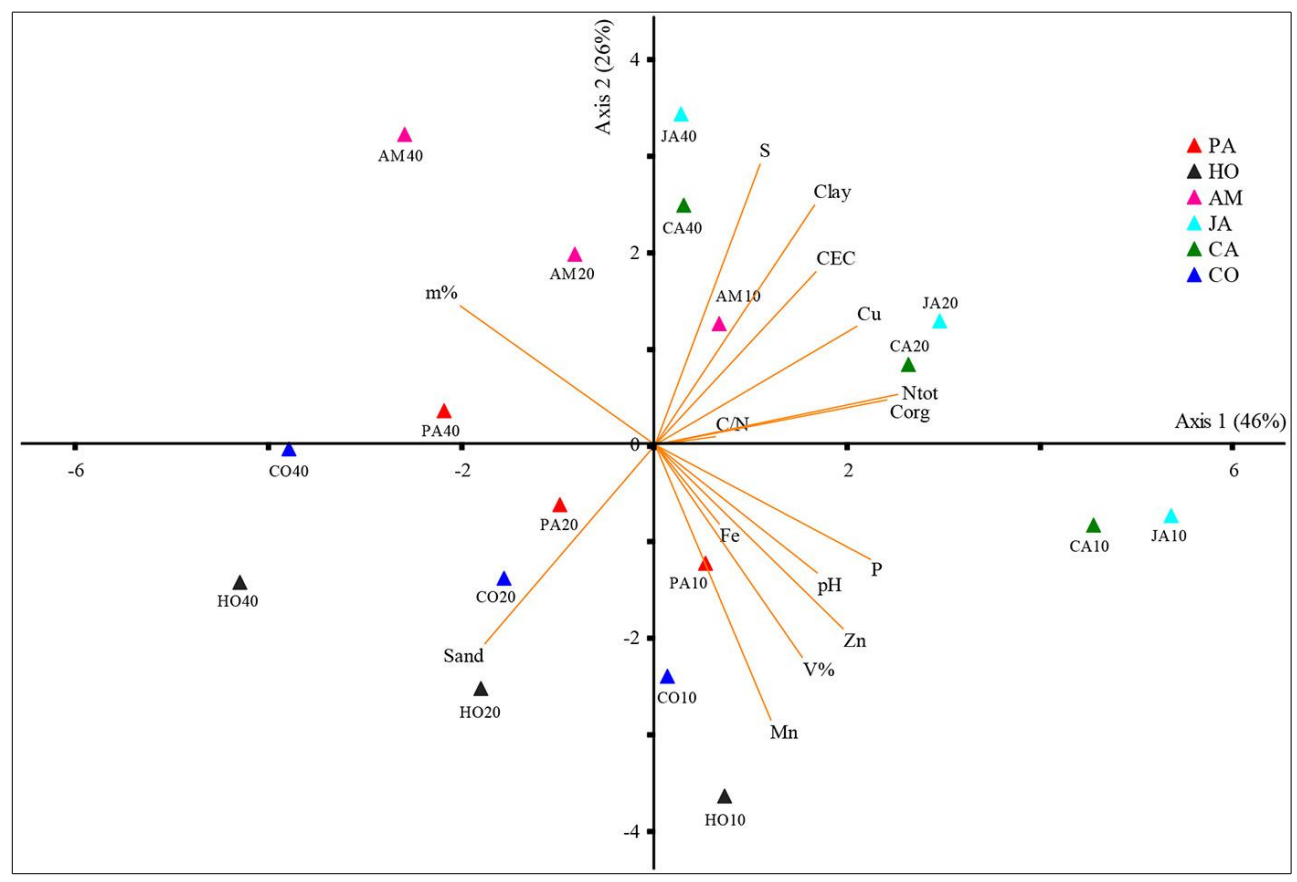




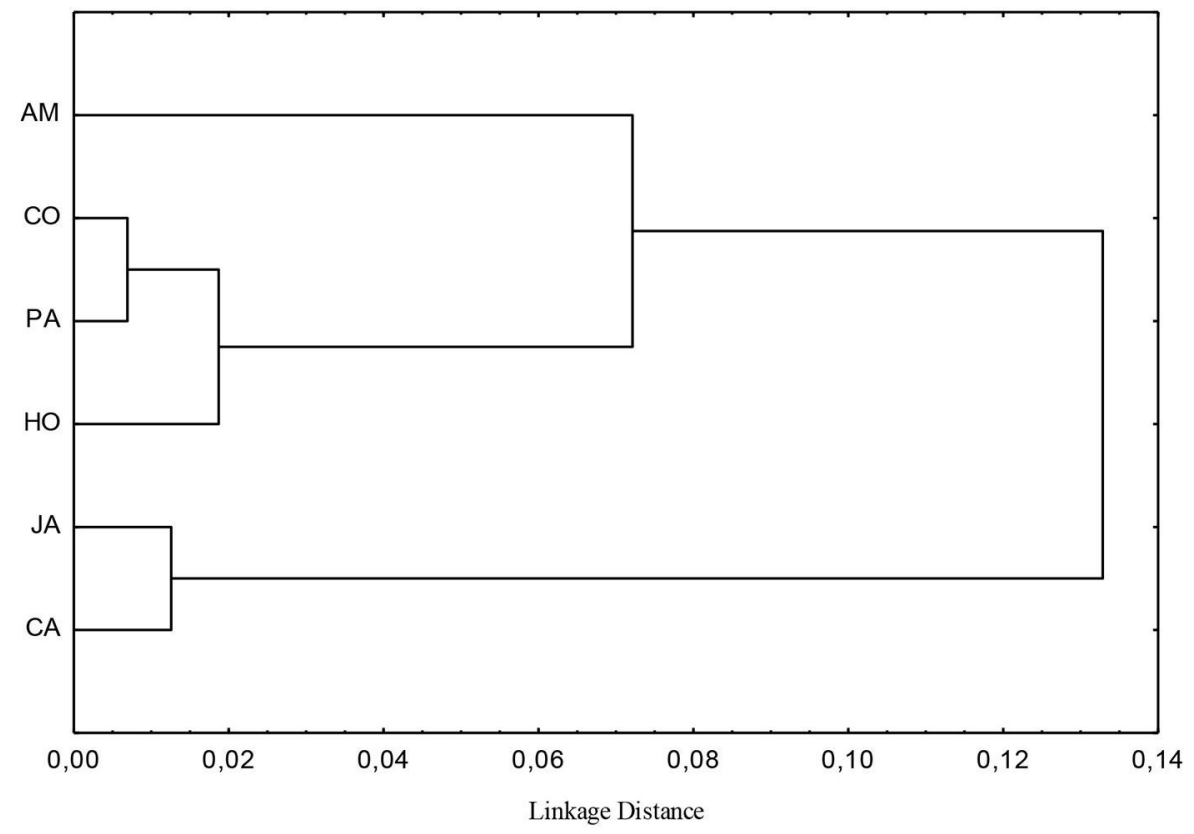

Fig. 7 - Cluster analysis on data from 0-40 cm soil layer of semideciduous Atlantic Forest remnants in the Metropolitan Campinas Region (MCR), Brazil. (PA): Paulínia; (HO): Holambra; (AM): Americana; (JA): Jaguariúna; (CA): Campinas; (CO): Cosmópolis.

\section{Discussion}

Higher concentrations of nutrients in the 0 $10 \mathrm{~cm}$ soil layer compared to those at deeper layers were observed in all the forest remnants analyzed, indicating that the soil surface likely had the conditions needed to buffer the atmospheric deposition. Additionally, organic matter content was higher in the surface layer, as commonly observed in tropical soils (Ostertag et al. 2008, Tang et al. 2010). A substantial litter layer on the soils (Tab. 1) also explained the higher available nutrients on the soil surface.

Soil samples from sites showing a clay texture (Campinas and Jaguariúna) contained higher levels of basic cations than those with a more sandy texture (Americana, Cosmópolis, Paulínia and Holambra) where leaching was increased. Soil physical parameters have important influences on hydrological processes and plant growth ( $\mathrm{Li}$ et al. 2007). The sand and clay fractions primarily differ in the number of ion exchange sites (Materechera $\&$ Mkhabela 2001). Therefore, the positive correlations between clay content and carbon, total nitrogen, sulfur and copper were likely due to the adsorptive properties of the fine soil particles to organic matter, as discussed by Feller \& Beare (1997).

The Corg, Ntot and the $\mathrm{C} / \mathrm{N}$ ratio provide information about the chemical status of soil (Härdtle et al. 2004, Leuschner et al. 2013, Xiaogai et al. 2013, Cools et al. 2014). These parameters are particularly important in tropical soils, where the availability of nutrients is low and the weathering rates are high (Feller \& Beare 1997). Many nutrients are released to the soil during the mineralization of organic matter, including $\mathrm{Ca}, \mathrm{Mg}, \mathrm{P}$, $\mathrm{K}, \mathrm{S}$ and micronutrients (Ross et al. 2008, SanClements et al. 2010). Therefore, the high Corg and basic cation ( $\mathrm{Ca}, \mathrm{Mg}$ and $\mathrm{K}$ ) contents found in the forest soils from Campinas and Jaguariúna, along with the low $\mathrm{C} / \mathrm{N}$ ratio, indicated that soil mineralization and litter turnover were more rapid, which provided optimal conditions for plant growth.

Positive correlations were found between the high concentrations of Ntot, measured primarily in soil samples from Jaguariúna and Campinas (Fig. 2), and the levels of Corg, available $\mathrm{P}$ and $\mathrm{S}, \mathrm{CEC}$ and the clay fraction (Tab. 3). These correlations suggest a direct impact on soil chemical properties of organic matter (Härdtle et al. 2004) and inputs of atmospheric nitrogen from vehicular emissions and fertilization of surrounding agricultural areas. Also, these activities likely contributed to the high levels of $\mathrm{S}$ in the soils of Campinas and Jaguariúna, whereas the industrial complex probably contributed to sulfur deposition in Americana and Paulínia. Indeed, in the Cosmópolis and Holambra forests which are more distant from the industrial complex, the S levels were lower, indicating that sulfur deposition decreases with increasing the distance from the emission source. In contrast to the other elements, S increased with depth, primarily in Campinas soils (17.9 g. $\mathrm{dm}^{-3}$ on the surface and $47.0{\mathrm{~g} . \mathrm{dm}^{-3}}^{-3}$ subsoil), indicating its accumulation at deeper soil layers.

Abiotic conditions in combination with at- mospheric inputs results in soil acidification, which affects the development of the forest (Horswill et al. 2008, Farr et al. 2009, Hédl et al. 2011, Badea et al. 2012). In the present work, the soils were extremely acidic $(\mathrm{pH}$ 3.6-4.5) in all forest fragments, caused by high aluminum saturation and low basic cations, as typically observed in different tropical forests (Stevens et al. 2009, Fujii et al. 2011, Whittinghill \& Hobbie 2012). However, the forest soils near the industrial complex (Paulínia and Americana) were more acidic $(\mathrm{pH}=3.6-3.9)$ than those located farther apart from industries near rural or urban sources $(\mathrm{pH}=4.0-4.5)$, indicating that acidic deposition increases near the industrial area.

The $\mathrm{pH}$ and base saturation are important indicators of chemical processes in the soil and thus are key descriptors for monitoring forest changes (Cools \& Des Vos 2011). The low $\mathrm{V} \%$ might have been related to the leaching of basic cations $\left(\mathrm{K}^{+}, \mathrm{Ca}^{2+}\right.$ and $\mathrm{Mg}^{2+}$ ), which had a direct influence on soil acidity and increase of $\mathrm{m} \%$ (Jobbágy \& Jackson 2001, Boruvka et al. 2005, Ok et al. 2007, Kimetu et al. 2008, Ke-Hui et al. 2010, SanClements et al. 2010), as well as on the availability of heavy metals (Wei et al. 2006, Wilson et al. 2008, Stevens et al. 2009). Furthermore, basic cations and organic matter buffer the soil acidity (Ross et al. 2008, Ke-Hui et al. 2010). Hence, the mobilization of $\mathrm{Al}$ and $\mathrm{Fe}$ at low $\mathrm{pH}$ values (4.2 and 3.8, respectively), as suggested by Ke-Hui et al. 2010, could explain the high levels of these elements in the Americana and Paulínia soils (Fig. 4 and Fig. 5).

The parent material, weathering processes and pollution inputs affect the content of heavy metals in the soil (Matos et al. 2001, Wilson et al. 2008, Song \& Gao 2011, Chrastný et al. 2012). Soils derived from basic rocks naturally have more heavy metals (including $\mathrm{Cu}, \mathrm{Ni}$ and $\mathrm{Zn}$ ) than those derived from sandstone, siltstone or gneiss (Wilson et al. 2008, Nagajyoti et al. 2010). In the Campinas region, Miranda \& Tomaz (2008) reported that the soil was the main source of aluminum, while for zinc, copper and sulphur the main sources were industries and vehicle emissions. Monaci et al. (2000) found high concentrations of aluminum, iron, copper, manganese and zinc in the particulate material originated from vehicular emissions. Therefore, the soil parent material (diabase) and the urban air pollution could both explain the high concentrations of $\mathrm{Cu}$ and $\mathrm{Zn}$ in the Campinas and Jaguariúna soils.

The PCA highlighted the direct relationship among the CEC, the Corg and the clay fraction. The variables were clearly separated under the criteria of soil acidity, nutrient availability and $\mathrm{m} \%$. The sand fraction in the Cosmópolis and Holambra soils was di- 
rectly related to the increase in nutrient leaching to deeper soil layers, whist it was related to the Al toxicity and high acidity in the Americana site. This separation was confirmed by cluster analysis that grouped the Jaguariúna and Campinas forests by the characteristics of more optimal chemical conditions and texture (primarily because of the proportion of clay). Such conditions contrast with the Americana forest soil, which was more acidic, characterized by higher levels of $\mathrm{Al}$ and lower exchangeable base cations, and sandy-clay texture. Soils from the Cosmópolis, Paulínia and Holambra forests were grouped because of their similar chemical and physical conditions.

\section{Conclusions}

Remnants of the semideciduous Atlantic Forest in the MCR are growing on soils with distinct chemical and physical conditions due to the parent material and the deposition of air pollution. The optimal chemical conditions (high contents of exchangeable bases, nitrogen, phosphorus and sulfur) were found in the clay soils of Jaguariúna and Campinas, which are more affected by rural or urban pollution and less impacted by the industrial complex. These soils are expected to show the best buffering capacity against environmental pollution. However, air pollution deposition was related to the acidification of sandy soils in forest fragments more influenced by the industrial complex. Therefore, the Atlantic Forest vegetation in Paulínia, Cosmópolis, Holambra and Americana might be more susceptible to air pollution than the forest remnants located in Campinas and Jaguariúna.

\section{Acknowledgments}

The authors wish to thank Programa SISBIOTA-BRASIL (proc. CNPQ 563335/2010 and proc. FAPESP 2010/52319-2) for financial support, Área de Relevante Interesse Ecológico Mata da Santa Genebra and Cooperativa Agropecuária Holambra for providing the area for soil sampling, Coordenação Especial para Restauração de Áreas Degradadas-CERAD, Mr. Paulo R. T. Ortiz for drawing Fig. 1, and Mrs. Cristiane Aguiar Silva and Mr. Francisco Ricardo da Silva for the help in field sampling.

\section{References}

Akselsson C, Hultberg H, Karlsson PE, Karlsson GP, Hellsten S (2013). Acidification trends in south Swedish forest soils 1986-2008 - slow recovery and high sensitivity to sea-salt episodes. Science of the Total Environment 444: 271-287. - doi: 10.1016/j.scitotenv.2012.11.106

Badea O, Bytnerowicz A, Silaghi D, Neagu S, Barbu I, Iacoban C, Iacob C, Guiman G, Preda E, Seceleanu I, Oneata M, Dumitru I, Huber V, Iuncu H, Dinca L, Leca S, Taut I (2012). Status of the Southern Carpathian forests in the long- term ecological research network. Environmental Monitoring Assessment 184: 7491-7515. - doi: 10.1007/s10661-011-2515-7

Binkley D, Son YW, Valentine DW (2000). Do forests receive occult inputs of nitrogen? Ecosystems 3: 321-331. - doi: 10.1007/s100210000029 Boruvka L, Mladkova L, Drabek O (2005). Factors controlling spatial distribution of soil acidification and $\mathrm{Al}$ forms in forest soils. Journal of Inorganic Biochemistry 99: 1796-1806. - doi: 10.1016/j.jinorgbio.2005.06.028

Chrastný V, Vanek A, Teper L, Cabala J, Procházka J, Pechar L, Drahota P, Penížek V, Komárek M, Novák M (2012). Geochemical position of $\mathrm{Pb}, \mathrm{Zn}$ and $\mathrm{Cd}$ in soils near the Olkusz mine/smelter, South Poland: effects of land use, type of contamination and distance from pollution source. Environmental Monitoring Assessment 184: 2517-2536. - doi: 10.1007/s10661011-2135-2

CETESB (2012). Relatório de qualidade do ar no Estado de São Paulo [Air quality report in the State of Sao Paulo]. Series Reports, CETESB, São Paulo, Brazil, pp. 125. [in Portuguese] [online] URL: http://www.cetesb.sp.gov.br/Ar/publi cacoes.asp

Cools N, Des Vos B (2011). Availability and evaluation of European forest soil monitoring data in the study on the effects of air pollution on forests. iForest 4: 205-2011. - doi: 10.3832/ifor 0588-004

Cools N, Vesterdal L, Des Vos B, Vanguelova E, Hansen K (2014). Tree species in the major factor explaining $\mathrm{C}: \mathrm{N}$ ratios in European forest soils. Forest Ecology and Management 311: 316. - doi: 10.1016/j.foreco.2013.06.047

Cotrufo MF, Santo AV, Alfani A, Batoli G, Cristofaro A (1995). Effects of urban heavy metal pollution on organic matter decomposition in Quercus ilex L. Woods. Environmental Pollution 89: 81-87. - doi: 10.1016/0269-7491(94)00041B

Domingos M, Klumpp A, Klumpp G (2003). Disturbances to the Atlantic Rainforest in Southeast Brazil. In: "Air pollution impacts on crops and forests: a global assessment" (Emberson L, Ashmore M, Murray F eds). Imperial College Press, London, UK, pp. 287-308. [online] URL: http:// www.cabdirect.org/abstracts/20043159554.html Domingos M, Bulbovas P, Camargo CZS, AguiarSilva C, Brandão SE, Dafré-Martinelli M, Dias APL, Engela MR, Gagliano J, Moura BB, Alves ES, Rinaldi MCS, Gomes EP, Furlan CM, Figueiredo AMG (2015). Searching for native tree species and respective potential biomarkers for future assessment of pollution effects on the highly diverse Atlantic Forest in SE-Brazil. Environmental Pollution 202: 85-95. - doi: 10.101 6/j.envpol.2015.03.018

EMBRAPA (1997). Manual de métodos de análise de solo [Manual methods of soil analysis] ( $2^{\text {nd }}$ edn). EMBRAPA-CNPS, Centro Nacional de Pesquisas de Solos, Rio de Janeiro, Brazil, pp. 212. [in Portuguese] [online] URL: http://www. researchgate.net/profile/Wenceslau_Teixeira/pub lication $/ 267038200$
Falkengren-Grerup U, Tyler G (1993). Experimental evidence for the relative sensitivity of deciduous forest plants to high soil acidity. Forest Ecology and Management 60: 311-326. - doi: 10.1016/0378-1127(93)90086-3

Farr C, Skousen J, Edwards P, Connolly S, Sencindiver J (2009). Acid soil indicators in forest soils of the Cherry River Watershed, West Virginia. Environmental Monitoring Assessment 158: 343-353. - doi: 10.1007/s10661-008-0588-8

Feller C, Beare MH (1997). Physical control of soil organic matter dynamics in the tropics. Geoderma 79: 69-116. - doi: 10.1016/S0016-7061 (97)00039-6

Ferretti M, Fischer R, Mues V, Granke O, Lorenz $M$ (2010). Basic design principles for the ICP forests monitoring networks. In: "Manual on methods and criteria for harmonized sampling, assessment, monitoring and analysis of the effects of air pollution on forests". UNECE ICP Forests Programme Co-ordinating Centre, Hamburg, Germany, Part II, pp. 4-22. [online] URL: http://www.icp-forests.org/Manual.htm

Filizola FF, Gomes MAF, Souza MD (2006). Manual de procedimentos de coleta de amostras em áreas agrícolas para analise da qualidade ambiental: solo, água e sedimentos [Manual of sample collection procedures in agricultural areas for environmental quality analysis: soil, water, and sediment]. EMBRAPA Meio Ambiente, Jaguariúna, Brazil, pp. 169. [in Portuguese]

Forzza RC, Baumgratz JFA, Bicudo CEM, Canhos DAL, Carvalho AA, Coelho MAN, Costa AF, Costa DP, Hopkins MG, Leitman PM, Lohmann LG, Lughadha EN, Maia LC, Martinelli G, Menezes M, Morim MP, Peixoto AL, Pirani JR, Prado J, Queiroz LP, Souza S, Souza VC, Stehmann JR, Sylvestre LS, Walter BMT, Zappi DC (2012). New Brazilian floristic list highlights conservation challenges. BioScience 62: 39-45. - doi: 10.1525/bio.2012.62.1.8

Fujii K, Hartono A, Funakawa S, Uemura M, Sukartiningsih Kosaki T (2011). Acidification of tropical forest soils derived from serpentine and sedimentary rocks in East Kalimantan, Indonesia. Geoderma 160: 311-323. - doi: 10.1016/j.geoderma.2010.09.027

Gao W, Cheng S, Fang H, Chen Y, Yu G, Zhou M, Zhang P, Xu M (2013). Effects of simulated atmospheric nitrogen deposition on inorganic nitrogen content and acidification in a cold-temperate coniferous forest soil. Acta Ecologica Sinica 33: 114-121. - doi: 10.1016/j.chnaes.20 13.01.008

Härdtle W, von Oheimb G, Friedel A, Meyer H, Westphal C (2004). Relationship between $\mathrm{pH}$ values and nutrient availability in forest soils the consequences for the use of ecograms in forest ecology. Flora 199: 134-142. - doi: 10.1078/ 0367-2530-00142

Hawkins JL, Sheppard MI, Jorgensen SS (1995). Predicting soil lead migration: how can ancient church roofs help? Science of the Total Environment 166: 43-53. - doi: 10.1016/0048-9697(95) 04516-4

Hédl R, Petrík P, Boublík K (2011). Long-term 
patterns in soil acidification due to pollution in forest of the Eastern Sudetes Mountains. Environmental Pollution 159: 2586-2593. - doi: 10.1016/j.envpol.2011.06.014

Högberg P, Fan H, Quist M, Binkley D, Tamm CO (2006). Tree growth and soil acidification in response to 30 years of experimental nitrogen loading on boreal forest. Global Change Biology 12: 489-499. - doi: 10.1111/j.1365-2486.2006. 01102.x

Horswill P, O’Sullivan O, Phoenix GK, Lee JA, Leake JR (2008). Base cation depletion, eutrophication and acidification of species-rich grasslands in response to long-term simulated nitrogen deposition. Environmental Pollution 155: 336-349. - doi: 10.1016/j.envpol.2007.11.006

Hovmand MF, Kemp K, Kystol J, Johnsen I, RiisNielsen T, Pacyna JM (2008). Atmospheric heavy metal deposition accumulated in rural forest soils of southern Scandinavia. Environmental Pollution 155: 537-541. - doi: 10.1016/j.envpol. 2008.01.047

Jobbágy EG, Jackson RB (2001). The distribution of soil nutrients with depth: global patterns and the imprint of plants. Biogeochemistry 53: 5177. - doi: 10.1023/A:1010760720215

Joslin JD, Wolfe MH (1992). Red spruce soil solution chemistry and root distribution across a cloud water deposition gradient. Canadian Journal of Forest Research 22: 893-904. - doi: 10.1139/x92-119

Kabala C, Szerszen L (2002). Profile distributions of lead, zinc, and copper in Dystric Cambisols developed from granite and gneiss of the Sudetes Mountains, Poland. Water, Air, and Soil Pollution 138: 307-317. - doi: 10.1023/A:10155916 07154

Ke-Hui L, Yun-Ting F, Fang-Ming YU, Qiang L, Fu-Rong L, Shao-Lin P (2010). Soil acidification in response to acid deposition in three subtropical forests of subtropical China. Pedosphere 20: 399-408. - doi: 10.1016/S1002-0160(10)60029$\mathrm{X}$

Ker JC (1997). Latossolos do Brasil: uma revisão [Oxisols of Brazil: a review]. Geonomos 5: 1740. [in Portuguese] [online] URL: http://gene ral.igc.ufmg.br/portaldeperiodicos/index.php/geo nomos/article/view/187

Kimetu JM, Lehmann J, Ngoze SO, Mugendi DN, Kinyangi JM, Riha S, Verchot L, Recha JW, Pell AN (2008). Reversibility of soil productivity decline with organic matter of differing quality along a degradation gradient. Ecosystems 11: 726-739. - doi: 10.1007/s10021-008-9154-z

Klumpp A, Domingos M, Klumpp G (2002). Foliar nutrient contents in tree species of the Atlantic Rain Forest as influenced by air pollution from the industrial complex of Cubatão, SEBrazil. Water, Air, and Soil Pollution 133: $315-$ 333. - doi: 10.1023/A:1012914720934

Leitão Filho HF, Pagano SN, César O, Timoni JL, Rueda JJ (1993). Ecologia da Mata Atlântica em Cubatão [Ecology of the Atlantic Forest in $\mathrm{Cu}$ batão]. Unesp/Unicamp, São Paulo, Brazil, pp. 184. [in Portuguese]

Leuschner C, Wulf M, Bäuchler P, Hertel D
(2013). Soil C and nutrient stores under Scots pine afforestations compared to ancient beech forests in the German Pleistocene: the role of tree species and forest history. Forest Ecology and Management 310: 405-415. - doi: 10.1016/j.foreco.2013.08.043

Li XG, Li FM, Zed R, Zhan ZY, BhupinderpalSingh $X$ (2007). Soil physical properties and their relations to organic carbon pools as affected by land use in an alpine pastureland. Geoderma 139 (1-2): 98-105. - doi: 10.1016/j.geoderma.20 07.01 .006

Lucas RW, Klaminder J, Futter MN, Bishop KH, Egnell G, Laudon H, Högberg P (2011). A metaanalysis of the effects of nitrogen additions on base cations: implications for plants, soils, and streams. Forest Ecology and Management 262: 95-104. - doi: 10.1016/j.foreco.2011.03.018

Materechera SA, Mkhabela TS (2001). Influence of land-use on properties of a ferralitic soil under low external input farming in southeastern Swaziland. Soil and Tillage Research 62: 15-25. - doi: 10.1016/S0167-1987(01)00202-1

Matos AT, Fontes MPF, Costa LM, Martinez MA (2001). Mobility of heavy metals as related to soil chemical and mineralogical characteristics of Brazilian soils. Environmental Pollution 111: 429-435. - doi: 10.1016/S0269-7491(00)000889

Mayer R, Liess S, Lopes MIMS, Kreutzer K (2000a). Atmospheric pollution in a tropical rain forest: effects of deposition upon biosphere and hydrosphere. I. Concentrations of chemicals. Water, Air, and Soil Pollution 121: 59-78. - doi: 10.1023/A:1005249615589

Mayer R, Liess S, Lopes MIMS, Kreutzer K (2000b). Atmospheric pollution in a tropical rain forest: effects of deposition upon biosphere and hydrosphere. II. Fluxes of chemicals and element budgets. Water, Air, and Soil Pollution 121: 7992. - doi: 10.1023/A:1005201732427

Miller DE, Watmough SA (2009). Soil acidification and foliar nutrient status of Ontario's deciduous forest in 1986 and 2005. Environmental Pollution 157: 664-672. - doi: 10.1016/j.envpol. 2008.08.008

Miller EK, Friedland AJ (1994). Lead migration in forest soils: response to changing atmospheric inputs. Environmental Science and Technology 28: 662-669. - doi: 10.1021/es00053a020

Miranda R, Tomaz E (2008). Characterization of urban aerosol in Campinas, São Paulo, Brazil. Atmospheric Research 87: 147-157. - doi: 10.10 16/j.atmosres.2007.08.002

Monaci F, Moni F, Lanciotti E, Grechi D, Bargagli R (2000). Biomonitoring of airborne metals in urban environments: new tracers of vehicle emission, in place of lead. Environmental Pollution 107: 321-327. - doi: 10.1016/S0269-7491 (99)00175-X

Nagajyoti PC, Lee KD, Sreekanth TVM (2010). Heavy metals, occurrence and toxicity for plants: a review. Environmental Chemical Letters 8: 199-216. - doi: 10.1007/s10311-010-0297-8

Nalon MA, Mattos IFA, Franco GADC (2008). Meio físico e aspectos da fragmentação da vege- tação [Physical environment and aspects of vegetation fragmentation]. In: "Diretrizes para a conservação e restauração da biodiversidade no Estado de São Paulo" (Rodrigues RR, Bononi VLR eds). Instituto de Botânica, São Paulo, Brazil, pp. 15-21. [in Portuguese]

Nriagu JO (1990). Human influence on the global cycling of trace metals. Paleogeography, Palaeoclimatology, Palaeoecology (Global and Planetary Change Section) 82: 113-120. - doi: 10.1016/S0031-0182(12)80025-3

Ok YS, Chang SX, Feng YS (2007). Sensitivity to acidification of forest soils in two watersheds with contrasting hydrological regimes in the oil sands region of Alberta. Pedosphere 17: 747 757. - doi: 10.1016/S1002-0160(07)60090-3

Ostertag R, Marín-Spiotta E, Silver W, Schulten J (2008). Litterfall and decomposition in relation to soil carbon pools along a secondary forest chronosequence in Puerto Rico. Ecosystems 11: 701-714. - doi: 10.1007/s10021-008-9152-1

Pouyat RV, Yesilonis ID, Szalavecz K, Csuzdi C, Hornung E, Korsós Z, Russell-Anelli J, Giorgio V (2008). Response of forest soils properties to urbanization gradients in three metropolitan areas. Landscape Ecology 23: 1187-1203. - doi: 10.1007/s10980-008-9288-6

Prado H (1997). Os solos do Estado de São Paulo: mapas pedológicos [The soils of São Paulo State: pedological maps]. Hélio do Prado, Piracicaba, Brazil, pp. 205. [in Portuguese]

Raij BV, Quaggio JA, Silva NM (1986). Extraction of phosphorus, potassium, calcium and magnesium from soil by an ion-exchange resin procedure. Communications in Soil Science and Plant Analysis 17: 547-566. - doi: 10.1080/001 03628609367733

Rolim GS, Camargo MBP, Lania DG, Moraes JFL (2007). Classificação climática de Köppen e de Thornthwaite e sua aplicabilidade na determinação de zonas climáticas para o estado de São Paulo [Köppen and Thornthwaite climate classification and its applicability in the climatic zones determination of São Paulo State, Brazil]. Bragantia 66: 711-720. [in Portuguese] [online] URL: http://www.scielo.br/pdf/brag/v66n4/22.pd f

Ross DS, Matschonat G, Skyllberg U (2008). Cation exchange in forest soils: the need for a new perspective. European Journal of Soil Science 59: 1141-1159. - doi: 10.1111/j.1365-2389. 2008.01069.x

Ruan XL, Zhang GL, Ni LJ, He Y (2008). Distribution and migration pf heavy metals in undisturbed forest soils: a high resolution sampling method. Pedosphere 18: 386-393. - doi: 10.1016/ S1002-0160(08)60029-6

SanClements MD, Fernandez IJ, Norton SA (2010). Soil chemical and physical properties at the Bear Brook Watershed in Maine, USA. Environmental Monitoring Assessment 171: 111-128. - doi: 10.1007/s10661-010-1531-3

Schaaf W, Wecker B, Pan T, Hüttl RF (2004). Changes in top soil properties of forest soils in north-eastern Germany due to long-term element accumulation. Plant and Soil 264: 85-95. - doi: 
10.1023/B:PLSO.0000047713.27594.70

Sebesta J, Šamonil P, Lacina J, Oulehle F, Houška J, Buček A (2011). Acidification of primeval forests in the Ukraine Carpathians: vegetation and soil changes over six decades. Forest Ecology and Management 262: 1265-1279. - doi: 10.1016/j.foreco.2011.06.024

Sharpley A (1995). Identifying sites vulnerable to phosphorus loss in agricultural runoff. Journal of Environmental Quality 24: 947-951. - doi: 10.2134/jeq1995.00472425002400050024x

Song F, Gao Y (2011). Size distributions of trace elements associated with ambient particular matter in the affinity of a major highway in the New Jersey-New York metropolitan area. Atmospheric Environment 45: 6714-6723. - doi: 10.1016/j. atmosenv.2011.08.031

Stevens CJ, Dise NB, Gowing DJ (2009). Regional trends in soil acidification and exchangeable metal concentrations in relation to acid deposition rates. Environmental Pollution 157: 313319. - doi: 10.1016/j.envpol.2008.06.033
Tang JW, Cao M, Zhang JH, Li MH (2010). Litterfall production, decomposition and nutrient use efficiency varies with tropical forest types in Xishuangbanna, SW China: a 10-year study. Plant Soil 335: 271-288. - doi: 10.1007/s11104010-0414-2

Tresmondi ACCL, Tomaz E (2004). Air pollution and the influence of sources on Paulínia (Brazil) and surroundings. International Journal Environment and Pollution 22: 490-505. - doi: 10.1504/ IJEP.2004.005683

Tresmondi ACCL, Tomaz E, Krusche AV (2005). Avaliação de $\mathrm{pH}$ e composição iônica das águas de chuva em Paulínia-SP [Evaluation of $\mathrm{pH}$ and Ionic composition of rainwater in Paulínia-SP]. Engenharia ambiental 2: 70-84. [in Portuguese] Verstraeten A, Neirynck J, Genouw G, Cools N, Roskams P, Hens M (2012). Impact of declining atmospheric deposition on forest soil solution chemistry in Flanders, Belgium. Atmospheric Environment 67: 50-63. - doi: 10.1016/j.atmos env.2012.08.017
Wei X, Hao M, Shao M, Gale WJ (2006). Changes in soil properties and the availability of soil micronutrients after 18 years of cropping and fertilization. Soil and Tillage Research 91: 120130. - doi: 10.1016/j.still.2005.11.009

Whittinghill KA, Hobbie SE (2012). Effects of pH and calcium on soil organic matter dynamics in Alaskan tundra. Biogeochemistry 111: 569-581. - doi: 10.1007/s10533-011-9688-6

Wilson MA, Burt R, Indorante SJ, Jenkins AB, Chiaretti JV, Ulmer MG, Scheyer JM (2008). Geochemistry in the modern soil survey program. Environmental Monitoring Assessment 139: 151-171. - doi: 10.1007/s10661-007-9822-

Xiaogai G, Lixiong Z, Wenfa X, Zhilin H, Xiansheng G, Benwang T (2013). Effect of litter substrate quality and soil nutrients on forest litter decomposition: a review. Acta Ecologica Sinica 33: 102-108. - doi: 10.1016/j.chnaes.2013.01. 006 